\title{
A LITERATURA DE TRANSMISIÓN ORAL
}

\author{
Domingo Blanco
}

Resulta, a primeira vista, un paradoxo falarmos de literatura, filla da escritura segundo a súa etimoloxía, littera, como obxecto cultural transmitido oralmente, como se dunha lectura en voz alta se tratase. Cómpre, pois, precisar que o termo "literatura" ha de entenderse como unha forma específica de arte verbal, sen que importe que a súa creación e transmisión se fagan a través da letra escrita ou da voz en vivo ou mesmo gravada.

Pero tamén é certo que a escritura que deu nome a este arte, ao longo dos séculos serviulle, sobre todo, de base para a súa conservación e difusión oral, que foi a maneira habitual de espallarse a literatura ata ben despois de establecemento da imprenta na nosa sociedade. E non podía ser de outro xeito, pois, como sabemos, ler e escribir foron actividades minoritarias ata a alfabetización de grandes masas da poboación, consecuencia directa da extensión da instrución pública que comeza no século XIX e que tivo en Galicia características especiais, nomeadamente dúas: a alfabetización só foi posible nunha lingua allea —o castelán- e o proceso non se consumou ata datas moi tardías (o período da segunda República).

Non foi, pois, un milagre que a inmensa maioría da poboación de Galicia permanecese apegada á literatura transmitida oralmente na súa lingua habitual, o galego, ata ben entrado o século XX. Alén diso, o progresivo espallamento da escritura permitiu a un nutrido grupo de galegos instruídos transcribir moitas pezas literarias orais e, en consecuencia, dar conta ás xeracións seguintes, instaladas xa na cultura de transmisión escrita, da enorme variedade, riqueza e espallamento social desta literatura que os mestres alemáns do século XIX bautizaran co nome de Volksliteratur, e que foi traducido como Literatura do pobo ou Literatura popular ${ }^{1}$.

1. Nas páxinas seguintes reprodúcense parcialmente contidos doutros traballos meus xa publicados, nomeadamente, Blanco (1996) e Blanco (1998). 
O que hoxe entendemos por literatura popular de tradición oral vén sendo un conxunto variado e variable de temas, formas e xéneros de arte verbal usados e transmitidos oralmente no seo dunha comunidade cultural, é dicir, o uso con pretensión artística (por modesta que sexa) da lingua dunha comunidade. Maniféstase ás veces como forma simplemente falada (contos, lendas, anécdotas, etc.), outras veces vai asociada á musica (letras de cantigas) ou mesmo á danza, e outras —as menos- preséntase como parte dunha representación escénica. En Galicia esta literatura ten una considerable importancia, tanto pola abundancia da súa produción como por ter conservado vivo ata hoxe un variado repertorio de grande interese histórico, etnolóxico e, mesmo, artístico, aínda que o recoñecemento do seu valor cultural supuxo un longo e dificultoso proceso aínda sen pechar definitivamente. A meirande parte da que hoxe se conserva está en galego e unha pequena parte en castelán. Presenta, en fin, unha serie de trazos que a caracterizan diante da literatura canónica de transmisión escrita e que, basicamente, son:

a) execución e transmisión oral.

b) variabilidade: non hai dúas execucións iguais dunha mesma peza.

c) aceptación colectiva — total ou parcial— por parte do grupo sociocultural na que se emprega.

d) o nome do autor (que poucas veces se coñece) carece de relevancia.

e) é un elemento funcional máis dentro do grupo social, onde se emprega para entreter, divertir, ensinar, establecer lazos de unión, ridiculizar defectos, aturar o traballo, galantear, agredir, pedir, gabar, entre outras funcións. Unha peza só é verdadeiramente popular cando é aceptada pola comunidade e se integra no conxunto das funcións comunitarias; e, cando perde as súas funcións, deixa de empregarse, vai esquecendo e acaba por desaparecer.

O repertorio conservado da literatura galega de transmisión oral, amais dalgunhas pezas curtas de teatro e de xéneros semiliterarios, como as fórmulas e xogos verbais — case sempre en verso- ditos, esconxuros, oracións, e, sobre todo, adiviñas e refráns, presenta dúas modalidades xenéricas básicas: o relato curto (conto e lenda) e a canción. Os textos conservados da primeira -agás unhas poucas excepcións - están en prosa; os da segunda, todos en verso.

Hoxe sabemos que esta literatura de tradición oral tivo en Galicia unha espléndida vitalidade dende - polo menos- o comezo do século XVIII ata o final do XIX: a súa abundancia, riqueza e variedade eran enormes, segundo os testemuños daquel tempo. O seu uso estaba xeneralizado entre a meirande parte da poboación — maioritariamente analfabeta — e para case todas 
as ocasións da vida. Conservaba plenamente as súas funcións tradicionais (divertir, relacionar, etc.) no seo daquela sociedade. Moi amplo era tamén o seu repertorio, como testemuñan as cuantiosas recolleitas que se fixeron naquel tempo e que, así e todo, non recollen máis que unha pequena parte. A formación deste repertorio seguiu un dobre proceso: dunha banda a invención ou adaptación de cantigas, contos, adiviñas, etc., para unha situación e un auditorio concretos, e doutra a escolma das mellores ou máis graciosas que creadores, re-creadores e oíntes gardaban na memoria para dicilas ou cantalas cando houbera ocasión: eran as chamadas "coplas sabidas" ou "contos vellos", que forman o cerne do repertorio tradicional desta literatura.

O carácter altamente funcional deste material verbal impulsaba constantemente o proceso de creación de novas pezas: en cada ocasión festiva inventábanse coplas (a improvisación era habitual) e calquera anécdota graciosa ou feito misterioso daba pé a un conto ou unha lenda. Nel, a muller tiña un marcado protagonismo, especialmente como creadora e intérprete de cancións. Pódese dicir que todos os seres, obxectos e sucesos da realidade cotiá eran tema da literatura oral do pobo: "Apenas hay acto de la vida, hasta el más vulgar, que no tenga su copla”, escribe Murguía. Era, pois, esta literatura unha ferramenta moi estimada e empregada para desenvolver unha chea de funcións importantes no seo daquela sociedade: velaí a clave que permite explicar a súa riqueza, variedade e espallamento.

Os escenarios e situacións en que se manifestaba — ben como acto verbal enxebre, ben acompañada de música e baile ou de xogos- variaban segundo cada ocasión. As principais situacións adoitaban ser as festas -relixiosas ou profanas-, xa foran públicas (romarías, Antroido, Maio, Reis, etc.), xa comunais (asociadas aos traballos agrícolas: fías, tascas, espadelas, seituras, etc.), xa familiares (vodas, sobre todo); os escenarios: a eira, o campo da festa, o adro da ermida, o alpendre ou a sala e o rueiro. Pero había, dende logo, situacións non festivas nas que esta literatura estaba presente.

En xeral, cada xénero quería unha situación e un escenario concretos (aínda que moitas veces adaptábase a varios): os contos e lendas botábanse nas xuntanzas laborais ou familiares de noite nas cociñas e con xente de toda idade; a taberna foi o escenario masculino por excelencia, onde se xuntaban os amigos (e, ás veces, os rivais) e se xogaba, contaba e cantaba o que noutros escenarios se silenciaba ou suavizaba; polos camiños cantaban os arrieiros, sen ninguén que os oíse, para aturar a monotonía; nas costuras cantábanse de cotío cantigas e cantigas; nas zapaterías, contos de toda caste; e mais en canta xuntanza houbera ocasión para o entretemento ou un anaco de tempo agradablemente compartido.

Algúns destes escenarios tiveron especial importancia como viveiros de cantigas, contos e outras formas de arte verbal de transmisión oral: os fiadei- 
ros (xuntanzas laborais e festivas do tempo de inverno), as ruadas (festas sinxelas, "pobres" — sen gaiteiro—, nas que o canto e o baile acompañábanse cun modesto pandeiro e mais con cunchas e ferreñas) e as regueifas (disputas en verso entre varios contrincantes polo pan da voda), onde se inventaron e espallaron centos de cantigas en galego, repetidas máis tarde aquí e acolá polos que as oíran.

Entre os que asistían ás festas e xuntanzas adoitaba haber algúns, moi estimados, con dotes especiais para a interpretación, como ocorrencia, boa voz, repertorio amplo, capacidade para improvisar, graza para contar, habilidade no manexo de instrumentos, etc., e eran eles os que máis contribuían a animar as reunións. Chamábanos para as festas de certa importancia, onde adoitaban competir con outros, e xuntaban ao seu arredor unha ampla concorrencia de oíntes, e tiveron grandísima importancia como transmisores e difusores da literatura oral popular. Tamén había verdadeiros especialistas en regueifas, que - malia as liortas que ás veces causaba o atrevemento do seu contido- atraían moita xente nas zonas onde eran usuais. Moi estimados eran, así mesmo, os bos contadores de contos, lendas e historias.

Pero, de cotío, calquera que participara en ruadas, fías e outras xuntanzas podía (e, ás veces, debía) interpretar pezas literarias (contos, adiviñas, etc. pero, sobre todo, cantigas): unhas sabidas de antes e recordadas entón e outras improvisadas alí mesmo; moitas veces había unha especie de competición entre individuos ou entre grupos (por exemplo, mozos contra mozas ou os dun lugar contra os doutro) que rivalizaban en botar coplas e outras mostras de enxeño: competir cantando era unha boa maneira de animar a festa. Estes cantares de desafío — habituais- deron pé a formas máis específicas como a enchoiada (na que dous mozos compiten por unha moza), o parrafeo (disputa con texto prefixado) e, sobre todo, a regueifa, que é a forma de desafío cantado máis especializada, máis coñecida e tamén máis agresiva. Moitas das pezas recollidas dende o século XVIII como parte do repertorio tradicional proceden, con toda seguridade, destes distintos tipos de desafíos. Sirvan de exemplo estas, de ton moderado, recollidas no século XVIII polo padre Sobreira (transcrito por Pensado 1974; 261, e reproducido en Blanco 1992: 139):

[Moza]:

¡Ou que piñeiro tan alto Enriba ten mil enredos.

O galán cando namora

nunca ten os ollos quedos.

[Mozo]:

¡Ou que piñeiro tan alto! 


\author{
¡Que piñas tan coloradas! \\ ¡Que rebique ten as nenas \\ en mentres non son casadas!
}

e mais esta, que recolle A. Suárez (1982: 17) de ton máis agresivo, que procede dunha regueifa:

\author{
O novio que hoxe se casa \\ algún día xa foi meu, \\ agora chupádelle os osos \\ ca carne cominlla eu.
}

O CONTO E A LENDA SOn as principais formas do relato oral galego. O conto, que é a forma máis abundante, é, basicamente, como é sabido, un relato en prosa (se ben existen algunhas narracións en verso catalogadas como contos), en xeral breve, de carácter ficticio e cunha certa inconcreción na caracterización das personaxes, do espazo e do tempo. A lenda é tamén un relato breve no que interveñen forzas ou personaxes sobrenaturais, pero, a diferenza do conto, ten pretensións de verosimilitude e presenta moita máis concreción no tempo, espazo e mesmo nos personaxes. Moitas veces estes dous tipos de relato non resultan fáciles de diferenciar.

Se ben o relato galego presenta unha notable variedade de temas, é a realidade concreta dos oíntes un factor condicionante decisivo na súa configuración verbal; o tipo de público, a capacidade do narrador e a función que se lle asigne ao relato determinan o seu grao de "realismo". Así, unha simple anécdota, ocorrida quizais nun entorno próximo aos que escoitan e contada con humor, resultará interesante para un público concreto e bo coñecedor do seu medio, e a súa función básica será a de divertir, ademais de informar; mentres que un conto marabilloso, con personaxes e situacións fantásticas e forte carga simbólica, irá dirixido aos que non precisan coñecer o miúdo da realidade (nenos, por exemplo) para disfrutar dun relato de ficción e aprender, ao mesmo tempo, normas elementais de conduta. Xa que logo, un narrador non poucas veces é un re-creador que modifica e adapta un relato segundo as circunstancias da súa execución: público, lugar, tempo dispoñible, etc. Segundo a maior ou menor presenza da realidade concreta no narrado, pódense distinguir na literatura galega de tradición oral cinco tipos básicos de relato:

1. Relatos anecdóticos: é o tipo máis dependente da realidade inmediata e adoita ser moi breve na súa forma, intenso no seu efecto cara ao público e tinxido de trazos locais, de maneira que aínda 
que o feito presuntamente real que lle serve de base non sucedera na zona onde se conta, aderézase con detalles que o encadren na realidade local dos que escoitan; moitos relatos deste tipo, mudando algúns aspectos do seu contido ou da súa forma, resultan válidos para calquera lugar e público e son, por iso, "exportados" con facilidade, entrando así no proceso de folclorización.

2. Relatos da realidade acostumada: neste tipo —que é o máis abundante- personaxes e ambiente pertencen á realidade coñecida polo público (normalmente, a do mundo rural galego), pero teñen carácter enteiramente ficticio (son conto, non verdade) e a esaxeración intervén con frecuencia na configuración do contido. Unha carencia de algo desexable (a fame, a escaseza material, a solteiría, etc.) empurra aos personaxes a intentaren superala realizando feitos por veces arriscados, por veces enxeñosos e por veces ridículos, pero case sempre fóra das normas habituais de conduta social, o que os leva a obter resultados dispares (éxito ou fracaso) que producen un efecto de comicidade ou de exemplaridade nos que escoitan.

3. Relatos da realidade sobrenatural: aquí o mundo máxico superponse ao real, vén en axuda del e modifica as leis que rexen os actos humanos dos personaxes do relato, que son así regulados por un ser ou un suceso sobrenatural, conforme ao sentir común. O desencadeante adoita ser tamén unha carencia material ou moral. Unhas veces é a satisfacción das necesidades elementais o que forza a intervención de elementos máxicos sobre a realidade problemática dos desposuídos (que é a materia habitual destes relatos); outras, esta carencia é de índole moral e está estreitamente relacionada coa conduta negativa (segundo o código moral da comunidade) dun personaxe, que é castigado grazas á intervención de forzas máxicas ou divinas. O efecto é sempre exemplarizante.

4. Relatos de animais: a realidade aparece aquí transformada conforme a un sinxelo código de símbolos, segundo o cal unha serie de animais familiares ao home presentan sentimentos, condutas e costumes humanos, especialmente a fala (que é o seu principal trazo caracterizador), a fame que impulsa os seus actos (comer e non ser comido), e unha xeira de vicios e calidades propios dos humanos: astucia (o raposo), burremia (o lobo), fachenda (o galo), etc..

5. Relatos marabillosos: son os máis afastados da realidade dos oíntes. Carecen de calquera pretensión de verosimilitude e os personaxes, o tempo e o espazo diferéncianse claramente dos que son habituais nos outros tipos de relato; nunca falta a presenza de ele- 
mentos máxicos ou esaxerados. En todo o espazo cultural europeo presentan practicamente a mesma estrutura, baseada nun conxunto limitado de funcións fixas e uns poucos personaxes básicos. Constitúen o tipo de relato de ficción por excelencia e, sen embargo, é posible que reflictan unha realidade remota na que a humanidade pasou dunha sociedade arcaica (cazadora, nómade, endógama) a outra moderna (agraria, sedentaria, exógama), o que a penas se percibe — despois de varios milenios de reelaboración literaria- na súa forma actual.

$\mathrm{Na}$ maior parte dos casos, os relatos galegos proceden de diversas tradicións orais e escritas orixinadas en lugares indeterminados e espallados polo ámbito indoeuropeo que, para poderen entrar no repertorio galego de tradición oral, tiveron que sufrir una xeira de modificacións para adaptarse ao novo público e seren aceptados por el. Un bo exemplo diso é o conto titulado Pra quen cucou o cuco (en Contos populares da provincia de Lugo, $\mathrm{n}^{\circ} 200$, recollido na escola de Guitiriz no curso 1955-56):

O tío Xan do Outeiro e máis o Bailón de Corbite, viñan un día prá vila de Guitiriz, pra arreglar a cobranza do susidio da vellez. Vindo polo camiño, sintiron cucar o cuco, e díxolle o tío Xan ao Bailón:

- Cucou pra min.

E díxolle o Bailón:

- Non, bo, que cucou pra min.

E, sobre desto, tiveron tal disputa, que acordaron levar o asunto a un avogado. Ao chegar ao despacho, contáronlle ao señor avogado o choio que os levaba xunto dil. I o avogado, despois de rascar un pouquiño a cabeza, dixolles:

- Poñan cincuenta pesos cada un, e despois dígolles pra quen cucou o cuco. Sacaron de carteira e botaron encima da mesa os cincuenta pesos cada un. Entón o avogado, botando mau aos cartos, dixo:

- Abora dígolles pra quen cucou o cuco: cucou... pra min.

Vencellado a un lugar (a vila luguesa de Guitiriz, neste caso) e cuns protagonistas con nome propio (o tío Xan do Outeiro e o Bailón de Corbite), coñecidos polo público da zona e posiblemente veciños (se ben Xan do Outeiro é tópico antroponímico das pezas cómicas populares en Galicia). Nesta versión luguesa cada un dos dous personaxes que oíran cucar o cuco manteñen e porfían que foi para el e confían na autoridade do avogado, que se aproveita da súa simpleza e lles saca os cartos. Trátase de personaxes clásicos do conto tradicional galego (os paisanos teimosos e pleiteiros, o avogado astuto e ganancioso, caracterizados todos eles como tipos que se repiten 
con frecuencia noutros contos), un entorno físico e social familiar (o camiño da vila, o subsidio de vellez) e unhas actitudes xeneralizadas no seu grupo humano (a consulta ao avogado e, sobre todo, a crenza en agoiros ou sinais da natureza como o canto do cuco, ao que aquí se lle atribúe o evidente significado de "promesa de prosperidade", vid. Chevalier \& Gheerbrant 1993: 385).

Parece de toda lóxica deducirmos — polo menos se non estamos familiarizados co mundo da transmisión folclórica- que o conto probablemente se orixinara en Guitiriz, a partir duns personaxes célebres e dunha anécdota sonada (real ou inventada), como sucede con tantos outros relatos desta caste. A moi estreita adaptación da materia narrativa a un auditorio concreto e local resulta aquí evidente, de maneira que o conto perdería boa parte da súa efectividade ou da súa aceptación noutras zonas onde o nome dos personaxes careza de sentido ou de connotacións, o lugar resulte descoñecido ou mesmo o canto do cuco nada signifique ou signifique outra cousa. Por iso resulta, cando menos, sorprendente descubrirmos que o escritor e editor valenciano do século XVI Juan de Timoneda o recolle — como outras moitas pezas do folclore oral daquel tempo- na colección de contos e anécdotas El Sobremesa y Alivio de caminantes (Timoneda s.a.: 231); que en 1627 tamén o ilustre paremiólogo Gonzalo de Correas o inclúe e explica no seu Vocabulario de refranes y frases proverbiales (Correas 1967; 479-480); que se recolle, así mesmo, no libriño anónimo alemán Burger-Lust de 1663 (MoserRath 1984: 147) e que, ata mediados do XVIII, rexístranse ata media ducia de versións do conto nesa lingua (Moser-Rath 1984: 458); e que, xa a fins do século XIX, é recollida tamén en Portugal no Porto por Teófilo Braga (1987 [1914]: 262-263). Lugares distantes, linguas diferentes, públicos heteroxéneos: ¿qué conclusións podemos tirar? Da versión portuguesa, nun principio, cabe pensar, que por mor do continuo intercambio cultural con Galicia, puidera ter unha estreita relación de familia, pero as versións castelás e alemás non parecen ter relación ningunha coa realidade galega que presenta o conto: o público valenciano do século XVI e, dende logo, o alemán do XVII e XVIII, mal saberían onde queda Guitiriz e moito menos quen eran Xan do Outeiro e o Bailón. Entón ¿̇onde e cando puido nacer este contiño e como se espallou?

Tanto a súa antigüidade coma a súa orixe resultan bastante problemáticas, o mesmo que determinar se algunha das versións coñecidas pode ser a fonte das outras. En todo caso non se encontra no Motiv-Index de Stith Thompson, polo que cabe pensar que podería tratarse dun relato de orixe ibérica. O sentido común e o método filolóxico inclínanse a atribuír, en principio, máis antigüidade ás versión testemuñadas máis cedo. Timoneda pono como explicación do dito popular "Por mi cantó el cuclillo", polo que hai que supoñelo bastante anterior á súa recollida, suposición dunha tradición 
oral que vén confirmada pola autoridade do mestre Correas; ademais parece probable que unha colección de facecias tan divulgada entre un público amplo e variado como a citada estea na orixe - polo menos- da versión portuguesa e da galega, dada a secular relación entre uns e outros.

Pero, se así fose, ¿̇como chegou a acadar o carácter marcadamente local da versión luguesa? Seguindo o proceso propio da transmisión folclórica: partindo dunha trama argumental básica, un receptor crea —ou recrea-, á súa vez, un texto no que se operan todas as transformacións necesarias para que resulte $1^{\circ}$ intelixible, $2^{\circ}$ aceptable e $3^{\circ}$ agradable á comunidade de oíntes á que este transmisor pertence, é dicir, sofre unha nova adaptación a un público diferente. As transformacións son, pois, de tres ordes: as da primeira (que poida ser entendido) atinxen ao idioma, que, neste caso, houbo de variar; as da segunda (que poida ser aceptado) teñen que ver co xeito de expresión, coa adaptación á fala da comunidade, e mais coa familiaridade dos personaxes e do asunto para a ese novo público; neste caso hai que subliñar a importancia - decisiva- da interpretación do canto do cuco como promesa de prosperidade e non como signo de infidelidade conxugal, tal como o entendía o público das versións castelás e mais da portuguesa; as da terceira (que poida ser estimado, é dicir, que manteña ou acrecente a súa eficacia literaria) afectan ao deseño e caracterización dos personaxes, á trama, á situación e ao modus dicendi: aquí os personaxes das versións castelás foron parcialmente substituídos por outros (incluídos os nomes) máis axeitados ao novo auditorio (o xuíz de Timoneda — solemne de máis— polo avogado — moito máis frecuentado e accesible-, dous "pacíficos, honrados y buenos hombres" — segundo a versión de Timoneda- por dous paisanos de aire pintoresco, concretos e ben coñecidos, entrados xa en anos pero non en sentido); o escenario cambia: de novo substitúense os trazos xerais polos concretos (a vila de Guitiriz, o subsidio da vellez, os cincuenta pesos) e cheos de connotacións para o novo público; e obsérvase un trazo de estilo propio da fala oral: a repetición onomatopeica (cucou o cuco) que reflicte axeitadamente a teimosía dos protagonistas. O cerne da trama argumental queda intacto, incluída — acertadamente- a lección final. Calquera transeúnte (un arrieiro, un soldado, un vendedor ambulante, un criado, uns segadores, etc.) puido levalo consigo ata a Terra Cha onde unha verdadeira recreación, axeitada para ser comprendida e gustada, conseguiu facer desta vella anécdota unha peza viva de literatura en galego de ampla difusión despois dun intelixente proceso de recreación.

O outro xénero dominante na literatura galega de transmisión oral é A CANTIGA, que constitúe o continxente máis numeroso do seu repertorio. Unha clasificación de base funcional abranguería os seguintes tipos: infantís, de labor, de festa e baile (a meirande parte das producidas en ruadas e xuntanzas 
ocasionais), rituais ou de costumes (en festas anuais como Antroido, Nadal, Maios, de romarías, etc.), de disputa (regueifas e outros desafíos) e de entretemento (os cantados fóra da festa ou celebración, de carácter máis individual). As cantigas populares galegas presentan tres trazos formais característicos na súa versificación: formas estróficas breves, isosilabismo e asonancia. As estrofas máis frecuentes son a copla, a muiñeira e o terceto, xunto co romance e as formas dos ditos e xogos infantís (xeralmente pareados). A súa temática sitúase no amplo marco da poesía folclórica occidental: os asuntos máis tratados son os sentimentos persoais (amor, soidade, desexo, reflexión), o trato social (galanteo, diversión, burla, disputa, etc.), a vida familiar (mais, sogras, etc.), o traballo, a festa, o medio natural (animais, paxaros, ríos, etc.) e a devoción relixiosa. Fronte ao tópico do sentimentalismo atribuído decote á literatura galega, a actitude predominante no cancioneiro de tradición oral é o humor, que —ben como comicidade aberta, ben como ironía- impregna case todos os temas, dende o amoroso ata o relixioso. Tal como o coñecemos hoxe, parece formado case todo durante os séculos XVIII e XIX; algunhas pezas son do XVII e unhas poucas, pola súa forma e temática, parecen supervivencias da tradición popular medieval.

A estrofa dominante dende o século XVII (polo menos) é a copla, composta case sempre de catro versos de oito sílabas (ás veces — poucas- de seis) con rima asonante nos pares, pero que, na súa execución, adoita presentar cinco ou seis versos (ben por repetición, ben por engadírselles ao remate versos baleiros); constitúe tamén a base da maioría das composicións longas, coma o romance, a regueifa, o parrafeo, etc.; polo xeral, adoita cantarse formando series.

Manteñen aínda unha presenza importante o terceto e a muiñeira. Esta estrofa antiga, que acompaña a danza e melodía do mesmo nome, presenta habitualmente a forma de dístico monorrimo de arte maior (estrofa de dous versos longos que riman entre eles) de ritmo ternario (xeralmente dactílico) e con cesura, pero - a diferenza do seu emprego na Idade Media - sen refrán; ás veces forma series paralelísticas nas que os versos dun dístico son repetidos parcialmente nos do seguinte, mesmo empregando a técnica medieval do leixaprén (Vendédem'os bois e vendédem'as vacas / e non me vendades o pote das papas. / Vendédem'o pote, vendede o cunqueiro / mais non me vendades o meu tabaqueiro). É a forma estrófica e rítmica máis característica da poesía tradicional galega.

O terceto, xeralmente de rima asonante nos impares, vencellado hoxe con formas románicas semellantes e non célticas, como en principio se afirmaba, é forma especialmente abundante e característica nas comarcas do Occidente galego. Moitos tercetos derivaron en cuartetas ao engadírenlles un verso máis ou, simplemente, repetilo; cántanse tamén formando series. 
O romance, xénero máis abundante (sobre todo na Galicia interior) do que se pensaba no século XIX, é a forma máis habitual da narración en verso. Adoitan estar en galego os de carácter humorístico ou familiar e, por veces, os líricos, pero a meirande parte están en castelán ou con abundantes castelanismos. Cantábanse acompañando aos labores de seitura, arrinca do liño, arada e outras semellantes; e, como sabemos, era un xénero habitual no repertorio dos cegos cantores. Os ditos e xogos dos nenos son, polo xeral, formas irregulares con rimas en pareado; ás veces cántanse e outras son recitados ou salmodiados. En fin, os vilancicos cantados polo pobo teñen como tema principal o nacemento de Xesús e as súas circunstancias e son a materia - total ou parcial - dos cantos de Nadal, Aninovo e Reis.

As cantigas constituían un modo especial de comunicación e de expresión naquel mundo de cultura oral, pero non polo seu contido, que se axustaba moitas veces (non sempre: xa vimos que algunhas cantábanse en soidade) ás necesidades da comunicación directa nun contexto concreto, coñecido e aceptado e ía sobre todo dirixido a un interlocutor (ou varios); o seu valor como ferramenta privilexiada da comunicación "artística" permitía expresar cantando tanto ocorrencias momentáneas como toda caste de temas cotiás (e outros que non o eran tanto); velaí algúns exemplos²:

- un dito gracioso:

$$
\begin{aligned}
& \text { Santo San Xusto da Fraga } \\
& \text { casamenteiro das vellas, } \\
& \text { ¿por qué non casais as mozas? } \\
& \text { ¿qué mal vos fixeron elas? } \\
& \quad \text { Chamácheme pouca roupa; } \\
& \text { se tes moita, teu proveito: } \\
& \text { menos teño que despir } \\
& \text { de noite cando me deito. }
\end{aligned}
$$

- unha gabanza:

$$
\begin{aligned}
& \text { Na misa estando un domingo } \\
& \text { miraches para min e riches: } \\
& \text { así a Dios lle parezas } \\
& \text { como a min me pareciches. } \\
& \quad \text { Miniñas de Vilanova } \\
& \text { ben vos podedes gabar, } \\
& \text { que non hai Virxen no mundo } \\
& \text { coma a Virxen do Cristal. }
\end{aligned}
$$


- unha queixa:

Olvidácheme por pobre,

eu a ti non sei por que;

ti pagácheme, eu pagueiche:

cada un garda o que ten.

Fun á tua casa por verte

e axexei polo ferrollo:

a ladra da tua mai

meteume un pau por un ollo.

- unha reflexión:

Os prados queren procuro,

os labramios labrador;

o que solteiro morreu

nunca foi namorador.

A moza que sai bonita

bastantes traballos ten;

n'hai cousa como ser fea:

non da traballo a ninguén.

- unha petición:

Xoaniña, Xoaneira,

dame un caravel, Xoaniña,

da túa caraveleira.

Ai, Maruxiña, non vaias á herba,

que vén o vento, Maruxa, e toda cha leva,

toda cha leva, lévacha toda,

ai, Maruxa, Maruxa, non seas tola.

- unha imprecación:

Mala arriada te leve,

muiño de Gondesán:

levei os zapatos novos,

truxen as zocas na man.

Mala morte mate ós homes

esganados cun cordel;

Madre miña de Mourente,

gardádeme o meu Manuel. 
- advertencias:

Toda a froitiña se come senón o verde limón; meniña que é parrandista dunha sale, de outra non.

Solteiriño, non te cases, mira que che ha de pesar: a vida do solteiriño é moi mala de olvidar.

- declaracións:

Manuel, Manueliño,

Manuel feito de cera, quen me dera se-lo lume que eu a Manuel derretera.

Moreniña, por morena téñoche o ollo botado; has de ser miña mullere ou non hei de ser casado.

- consellos:

Nas palabras dos canteiros, meniñas, non vos fiés: collen os picos e vanse. Meniñas ¿qué lles farés?

Non hai cantiga no mundo que non teña seu refrán; nunca ninguén faga conta senón do que ten na man.

- burlas:

Meniña dille a teu pai que se veña ver conmigo; tanto é o que me debe que non me paga contigo. Moza da camisa allea, a do pañuelo emprestado, dice a dona do xustillo que lle leves o refaixo. 
- preguntas e respostas de toda caste:

$$
\begin{aligned}
& \text {-Casadiña de tres días } \\
& \text { ¿quen che levou o color? } \\
& \text {-Nin solteira nin casada } \\
& \text { nunca cho tuven mellor. } \\
& \quad \text {-Cantan os galos pra o día, } \\
& \text { érguete, meu ben, e vaite. } \\
& \text {-¿Cómo me hei d'ir, queridiña, } \\
& \text { como me hei d'ir e deixarte? }
\end{aligned}
$$

E así practicamente todos os temas de conversa que se podían manter naquela sociedade plenamente instalada na comunicación oral.

Pero se os contidos son, en xeral, materia común de comunicación que todos poden comprender, a forma lingüística da cantiga si que ten algo de especial: o verso, a métrica, a rima, a relativa complexidade da construción da estrofa, a brevidade (é dicir, a condensación do contido) e, dende logo, a competencia idiomática que esixe (sobre todo se se improvisa no momento), que non estaba ao alcance de todos, cando menos non de maneira convincente e no intre oportuno. Por iso o público admiraba aos que sabían falar en verso e con xeito. Esta configuración verbal, de elaboración máis complexa que as formas comúns de comunicación, esta forma "artística" dáballe ao contido que transmitía un valor especial, máis contundente, máis expresivo, que crea máis expectativas nos oíntes e participantes.

Tamén o feito de ser cantada confírelle á cantiga varios trazos que lle dan un carácter diferente e, se cabe, aínda máis especial entre as formas de arte verbal: a música transmítelle unha certa solemnidade, tamén certa distancia que suaviza, ensordina o contido verbal; certa sensación de artificio, que sitúa o enunciado nunha dimensión distinta, un pouco fóra das regras da comunicación directa e transmite unha sensación de menor inmediatez ao diálogo entre o que canta e os que escoitan; un sentido "artístico" nunca lonxe da admiración (ou da decepción) inseparable da expectativa dos que escoitan; tamén serve —xunto coa configuración verbal (especialmente a métrica) da que é solidario- para equilibrar a mensaxe verbal que transmite o conxunto (temperar o impacto directo, disimular incoherencias, resaltar mensaxes pouco expresivas) e para complementar o artificio da mesma métrica, da que é un elemento artístico inseparable. Estes dous poderosos medios formalizadores da literatura cantada — a métrica e a música — son, pois, os que dan á cantiga a seu carácter singular — especialmente apreciadocomo forma de comunicación verbal.

Ademais, este plus de esixencia, de complexidade da cantiga continuaba na súa execución en público: non é tan sinxelo cantar (ben) coma falar; e aí 
é onde factores coma a voz, a graza, o enxeño, a capacidade para atacar ou defenderse con xeito e outros inclinaron algunhas cantigas cara ao éxito, a memorización e a transmisión posterior. En xeral, pódese afirmar que o contexto da cantiga tiña na maioría dos casos (festas, xuntanzas, disputas) unha complexidade que non se atopa nos xéneros narrativos.O repertorio de melodías das cantigas, sendo abundante, presenta menos variedade que o das letras, pois case sempre unha mesma melodía servía para moitas letras. Este compoñente musical das cantigas ten sido de cotío esquecido ou ignorado na análise e valoración destas pezas, por máis que ás veces resulta decisivo para o seu éxito e transmisión.

A compoñente literaria, a letra, ten como materia prima a fala dos seus oíntes, o código lingüístico dunha comunidade, e ten como fronteira o repertorio verbal desta. O uso do idioma vén condicionado por dous factores esenciais: a execución oral e un público posuidor dunha competencia idiomática limitada e moi concreta (ligada aos usos locais e ao rexistro coloquial) e, en todo caso, iletrado na súa inmensa maioría. A sinxeleza idiomática como imperativo para unha comunicación eficaz é, polo tanto, unha esixencia ineludible na lingua literaria destas pezas, que non terían razón de ser nin posibilidade de existir se non foran comprendidas polos oíntes.

A literatura do canto galego de tradición popular emprega unha retórica en consonancia coa sinxeleza idiomática e necesidade de comunicación directa que lle é consubstancial. Así, os recursos que máis abondan son dous procedementos tan elementais coma eficaces, que comparte co resto das literaturas orais de Occidente: a repetición e a antítese, que responden ás funcións básicas de intensificar e contrastar conceptos. Sírvanos como exemplo da primeira esta cantiga recollida en 1880 (pero, sen dúbida, de moi antiga tradición):

Como colebrexan as troitas no río eisí colebrexa teu corpo frolido; como colebrexan as troitas na iauga eisí colebrexa túa cara salada

E como mostra da segunda, esta copla ben coñecida na nosa literatura e presente, así mesmo, nas das áreas culturais veciñas:

Algún día por te ver

abría sete ventanas;

ahora por te non ver,

todas as teño cerradas. 
Cando, ás veces, os cantadores non desexaban que unha cantiga fora enteiramente comprendida ou, polo menos, non comprendida por todos os oíntes, a enunciación explícita dun contido con mención de feitos ou persoas era substituída pola alusión, que permitía tratar calquera tema (sempre que se fixera con tacto), que os iniciados identificaban sen dificultade e que evitaba tensións e conflitos:

\section{¿Acórdaste ti, meniña, \\ daquela noite de vrao? \\ Ti contabas as estrelas, \\ eu as areas do chao.}

A hipérbole e a ironía son tamén dous trazos característicos na lingua literaria das nosas cantigas, tanto pola súa frecuente presenza como pola visión do obxecto que impoñen e que coincide, en boa medida, coa perspectiva humorística, que tanto peso ten no cancioneiro galego. Como exemplos dun e doutra:

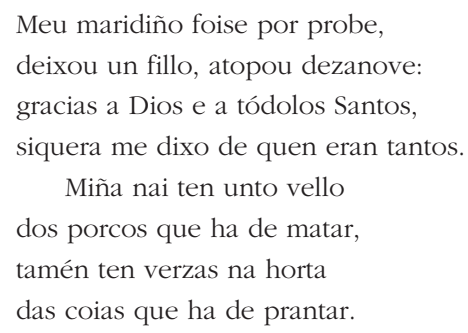

Son moi abundantes tamén os apóstrofes, coma nesta:

$$
\begin{aligned}
& \text { Esta noite e mais a outra } \\
& \text { e mais a outra pasada, } \\
& \text { miña pereiriña nova } \\
& \text { ¡case quedas abalada! }
\end{aligned}
$$

E a elipse, que vén compensar os efectos da repetición, coma na seguinte copla, marcada polo paralelismo sintáctico e semántico:

Te-lo sombreiro de croques,

chaqueta de vareadas,

polainas de rebeliscos,

zapatos de mordiscadas. 
Como corresponde a un xénero de execución e transmisión oral, a lingua das cantigas populares galegas abunda en fórmulas e frases fixas, que se repiten de vez en cando e teñen a función de facilitar a construción da estrofa, especialmente cando esta se improvisa. Así, achamos con frecuencia versos que se repiten iguais en varias cantigas, como "Miña mai e maila túa", "O cura e maila criada", "Pasei pola túa porta", "Este pandeiro que toco", etc.; estes versos de apoio multiplícanse nas coplas repentizadas, como as regueifas, especialmente cando duran varias horas, e nas fórmulas sintácticas que se enchen segundo cada ocasión. Vállannos como exemplos as dúas coplas do Padre Sobreira reproducidas na páxina 98 e mais estoutra, tamén recollida por Sobreira e construída segundo o esquema "As rapazas de [un lugar] / teñen [un defecto ou unha virtude,/ as de [outro lugar] / teñen [o contrario]:

\author{
As nenas de Bonaval \\ traguen plata nas orellas; \\ mas as da Caldeiraría \\ traguen cagallas de ovellas.
}

Hai, en fin, fórmulas, que poden ser estrofas enteiras, de iniciación ( $A$ regueifa está na mesa, / que é de pan de centeo, / o muiño que a moeu / non tiña capa nin veo), de salutación (Que viva por moitos anos, etc.), de despedida (Esta vai de despedida...; Adiós, miña meniña...) e outras.

As estrofas de dous, tres e catro versos (que son as que máis abundan) adoitan presentar unha estrutura bimembre; o primeiro elemento pode ser un imperativo, un vocativo ou unha condición, pero, con máis frecuencia, unha enunciación; o segundo elemento é complementario do primeiro, xeralmente unha explicación ou unha continuación, un desenvolvemento, unha comparación, unha resposta ou unha conclusión. É tamén frecuente que a bimembración sexa dobre, é dicir, que se dea en cada unha das partes da estrofa, como nesta letra na que se combinan paralelismo e antítese:

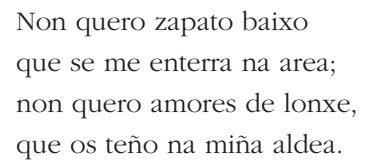

Os procedementos de relación entre un elemento e outro, ademais dos consabidos de tipo fónico e métrico (rima, regularidade dos versos, etc.), son de carácter sintáctico (unha parte é o suxeito e a outra o predicado, por exemplo) e semántico (relacións de semellanza ou de diferenciación, en 
correspondencia cos recursos da repetición e antítese que temos visto) e, en menor medida, secuencial (repetición de versos enteiros ou parte deles). Os procedementos sintácticos implican a distribución das funcións oracionais entre as dúas partes da estrofa, de maneira que a cada unha asígnaselle unha función sintáctica ben delimitada no enunciado global. As variantes son numerosas: a estrofa pódese artellar en dúas proposicións dunha oración xustaposta (como o exemplo anterior), nas dunha composta por coordinación (O vello perdeu a vella / entre a muruga do liño // e agora o vello chora / polo seu agarimiño) ou como suxeito fronte a predicado, ou suxeito + predicado fronte a complementos nunha oración composta por subordinación (Páxaro mixiriqueiro / heiche de cortar o pico // porque levas os recados / a donde está don Benito), amais dunha xeira de combinacións semellantes, entre as que sobresaen a secuencia pregunta + resposta (Nena que vende-las peras, / ¿cantas che mandaron dar?// Para ti, meu queridiño, / non mas mandaron contar) e a presenza da función apositiva (case sempre axudada polo apóstrofe) nun dos elementos (Divino san Cayetano / feito de pau de cerdeira // libraime, santo bendito, / dunba muller cabuxeira).

Os procedementos semánticos, ademais de presentar — como vimos- unha relación xeral de sentido na que a segunda parte da estrofa é desenvolvemento ou explicación da primeira ou comparación de accións paralelas, adoitan establecer unha relación de semellanza ou contraste entre ambas partes mediante a presenza —ás veces repetida- de unidades léxicas (palabras ou mesmo frases enteiras) de sentido, ben oposto, ben semellante, como na muiñeira e na copla seguintes:

Quérote moito polo tempo enxoito;

polo mollado, nin pouco nin moito

Rabeache pola peneira,

rabeache por peneirar,

rabeache por ter un mozo,

rabeache por te casar.

Moitas veces, sen embargo, o primeiro elemento da estrofa non é senón un pretexto para a enunciación do segundo, que é o verdadeiro portador do sentido:

Catro con cinco son nove,

para doce faltan tres;

se che faltei algún día,

aquí me tes outra vez. 
Non sempre a estrutura das cantigas é bimembre: con moita frecuencia é enumerativa e dela resultan tantas partes como permitan as dimensión da estrofa, como na coñecida "Vexo Vigo, vexo Cangas, / tamén vexo Redondela, / vexo a ponte de Sampaio, / camiño da miña terra", e en moitas outras.

A TRANSMISIÓN E CONSERVACIÓN deste conxunto de pezas de arte oral presentan en xeral máis complexidade do que cabía esperar da súa relativa sinxeleza. No caso de Galicia, cando, a partir de 1867, xorden as primeiras voces queixándose da invasión de cantigas en castelán que ameazaban con substituír as tradicionais en galego (Valladares, Murguía, Saco), este mundo de oralidade en galego empézase a sentir ameazado, e foi este sentimento un dos principais factores que motivou o transvase á escritura desta literatura de execución e transmisión oral, de maneira que quedase preservada dunha posible desaparición. E foi así — presa, fixada e reducida na escritura- como chegou ata hoxe a maior parte deste repertorio que, doutro modo, teríase esquecido ou deteriorado irremisiblemente. Salvouse pero sufriu unha fonda transformación.

A maioría das pezas que hoxe conservamos da literatura de transmisión oral chegaron a nosoutros principalmente de dúas maneiras. A primeira, a través da voz humana, seguindo unha cadea de transmisión que non se interrompeu nunca, se ben modificando algo, ás veces, o texto orixinario: aínda hoxe podemos escoitar contos ou cantigas, vivos na nosa tradición oral, que teñen centos de anos de antigüidade e foron transmitidos de viva voz ata chegar á nosa xeración. Foron tamén moitos, sen embargo, os que, circulando noutro tempo de boca en boca, viron interrompida a súa transmisión e nunca chegaron ata nós ou chegaron moi deformados: dalgúns deles sabemos que existiron, doutros só temos a suposición da súa existencia.

En efecto, ese instrumento de comunicación universal e eficaz que é a vOZ humana, presenta unha limitación determinante: só é capaz de chegar a oíntes próximos e nun tempo presente, e, deste xeito, unha cantiga ou un conto executados oralmente só poden ser transmitidos aos oíntes que estean alí naquel intre preciso; estes poderán transmitilos, á súa vez, a outros oíntes repetindo o procedemento e introducindo en cada nova reprodución — de maneira consciente ou inconsciente- variacións (en xeral pequenas) respecto ao texto orixinario. Así, calquera coñecedor e usuario da literatura transmitida oralmente vaise fornecendo ao longo da súa vida dun repertorio de cantigas, narracións e outras formas, de maneira que, de todas as pezas literarias que vai escoitando, só conserva na memoria (e repite, cando vén ao caso) as que, por diversos motivos (oportunidade, beleza, graza, alusións, adaptación a unha situación, etc.) lle gustan ou interesan, mentres que a maioría, que pasan sen pena nin gloria e esquécenlle axiña, constitúen o 
que podíamos chamar o "repertorio ocasional", que se renova constantemente.

O segundo modo de transmisión de pezas literarias populares é a través da escritura: nun momento determinado un individuo instruído escoita unha peza oral que lle resulta interesante e, non confiando na fraxilidade da memoria humana, decide conservala escribíndoa nun papel, co cal —se ten sorte- asegura a súa pervivencia por moito tempo. Ben é certo que este procedemento supón unha redución, un empobrecemento (especialmente cando se trata de cantigas, combinacións inseparables de texto e melodía) respecto á súa existencia oral, pero permitiu que moitos textos que serían moi probablemente esquencidos na transmisión oral puideran superar os atrancos do espazo e do tempo e chegar ata nosoutros.

No tempo actual existen tamén outros modos de transmisión descoñecidos no pasado: a gravación magnética da voz, que vén sendo empregada de cotío na segunda metade deste século nas recolleitas de material literario e literario-musical, con evidentes vantaxes sobre a escritura, e a gravación audiovisual, que permite conservar (polo menos parcialmente) un elemento fundamental na execución de textos orais: o contexto no que se executa, que, en moitas ocasións, é a clave para podermos entender o verdadeiro sentido e valor dunha peza literaria.

Este conxunto de pezas de arte verbal creadas (case sempre), interpretadas e transmitidas oralmente, ao ser trasladado á escrita, é dicir, cambiando o vehículo da súa transmisión, cambiou tamén o seu público, afastando os analfabetos, que constituíran o público tradicional desta literatura oral, e acercándose aos letrados; e modificou substancialmente a performance dos xéneros orais en varios aspectos importantes: pasouse así na percepción dunha cantiga da voz humana aos signos gráficos, do aire ao papel, do son ao silencio, do oído á vista, dun público presencial concreto — con frecuencia partícipe- a uns lectores individuais descoñecidos e, en fin, dunha realización variable a un texto fixado. O público receptor, heteroxéneo, entre o que hai coñecedores das versións orais das cantigas transcritas pero — sobre todo- descoñecedores, recibe un resultado único dunha transmisión complexa de seu- que lle pon diante dos ollos ese repertorio oral, que agora presenta unha realidade substancialmente distinta a aquela que os colectores coñeceran cando decidiron conservalo e facelo chegar aos lectores do seu tempo e, en último termo, os lectores de calquera tempo.

Moitos aspectos substanciais da cantiga popular quedaron no camiño neste proceso; o principal foi a compoñente musical no caso das cantigas, pero tamén outros elementos da performance oral como a entoación, a calidade e inflexións da $\mathrm{VOz}$, a graza dos intérpretes na execución, as reaccións e intervencións dos oíntes, e o ambiente en xeral. A crítica actual tende a sa- 
lientar (e non lle falta razón) a importancia do contexto e a execución dos diversos aspectos que fan callar unha comunicación oral nun momento e situación concretos como factores decisivos para configurar o relato ou o canto orais na súa dimensión real (é dicir, a que tivo no momento da súa execución) e non a reconstrución de que foron obxecto na translación e adscrición forzada ao mundo da literatura escrita, onde pasaron a ser obxecto de simple lectura, xulgados agora segundo os canons propios da literatura feita para lectores. En efecto, o desaxuste non ofrece dúbidas: a letra dunha cantiga, lida nunha folla de papel, resulta case sempre valorada de moi distinta maneira que cando é escoitada na súa enunciación oral e acompañada dunha melodía (que pode por si soa provocar o seu éxito, como vén ocorrendo a cada intre na canción convencional do noso tempo).

En realidade, estes dous modos de transmisión supoñen na práctica dúas existencias (Wiora 1959) ben diferenciadas: unha existencia primaria na que estas obras literarias, creadas ou adaptada para se transmitiren e difundiren mediante a voz humana entre un público concreto de oíntes, desenvolven no grupo social unha función ou unha serie de funcións, como temos visto. Cando unha peza da tradición oral perde o seu valor funcional no grupo social, déixase de usar, esquécese e desaparece. A meirande parte das pezas literarias do repertorio oral galego viviron só esta existencia. A existencia secundaria desa literatura empeza cando un sector de público con capacidade para ler e escribir fixa por escrito unha parte destes textos executados oralmente e inicia un novo modo de transmisión entre un novo público (letrado) e en novos contextos, nos que predomina a recepción individual, e onde, equiparada funcionalmente á literatura escrita, adoita ser considerada como un valor cultural secundario. Queda, pois, nesta existencia profundamente modificada —empobrecidacomo acto de fala, pero apta para unha conservación e transmisión indefinidas. A maior parte do repertorio actualmente coñecido da literatura galega de transmisión oral chegou ata nós nesta existencia secundaria.

\section{REFERENCIAS BIBLIOGRÁFICAS}

Blanco, Domingo (1992): A poesía popular en Galicia 1745-1885. Vol. 1. Vigo: Xerais.

Blanco, Domingo (1996): "A literatura popular", in A. Ansede Estraviz et al.: Historia da literatura galega. Vol. 8 . Santiago de Compostela: AS-PG / A Nosa Terra, 225-256.

Blanco, Domingo: (1998): "A literatura no canto popular", in C. Villanueva / Grupo Milladoiro (coords.): O feito diferencial galego na música. Vol. 2. Santiago de Compostela: Museo do Pobo Galego, 141-166. 
Braga, Teófilo (1987 [1914]): Contos tradicionais do povo português. Vol. 1. Lisboa: Dom Quixote.

Chevalier, J. \& A. Gheerbrant (1993 $)$ : Diccionario de los simbolos. Barcelona: Herder.

Contos populares da provincia de Lugo. Vigo: Galaxia, 1963.

Correas, Gonzalo de (1967): Vocabulario de refranes y frases proverbiales. Ed. Louis Combet. Bordeaux: Institut d'Etudes Ibériques et IbéroAméricaines de l'Université.

Moser-Rath, Elfriede (1984): Lustige Gesellschaft. Schwank und Witz des 17. und 18. Jahrbunderts in kultur- und sozialgeschichtlichem Kontext. Stuttgart: Metzler.

Pensado, J. L. (ed.) (1974): Opúsculos lingüísticos gallegos del siglo XVIII. Vigo: Galaxia.

Suárez, Andrés (1982): A regueifa. Vigo: Castrelos.

Thompson, Stith (1955-1958 [1932-1937]): Motif-index of folk-literature. 6 vols. Ed. revisada. Bloomington: Indiana University Press.

Timoneda, Juan de (s.a.): El Patrañuelo. El sobremesa y alivio de caminantes. Valencia: Prometeo [ed. baseada na de 1563].

Wiora, Walter (1959): "Der Untergang des Volksliedes und sein zweites Dasein”, in Das Volkslied heute. Kassel / Basel: Bärenreiter, 9-25 
APÉNDICE

\section{CUENTO LVII}

Por qué se dijo: Por mí cantó el cuclillo.

Paseándose por fuera de la ciudad una tarde dos pacíficos, honrados y buenos hombres, que iban en busca de sus mujeres, oyeron cantar un cuclillo. Dijo el uno dellos:

- Por vos ha cantado el cuclillo, compadre.

- No, sino por vos — dijo el otro.

Vinieron en tanta contienda sobre esto, que fueron delante el juez para que lo averiguase. Viendo el juez la locura dellos, hízoles formar proceso, y al cabo de haber ellos gastado algunas blanquillas, sentenció diciendo:

-Habéis de saber, buenos hombres, que por mí ha cantado el cuclillo; por eso andad con Dios.

(Juan de TIMONEDA, El Sobremesa y alivio de caminantes, Valencia, s. a. $\left[1563^{1}, 1569^{2}\right]$.

\section{POR MI CANTO EL CLUQUILLO [SIC]; POR EL JUEZ CANTO EL CLUQUILLO.}

Iban dos caminando, y cada uno tenía al otro por cornudo; oyeron cantar el cu-cu y dijeron uno a otro,: "Por vos cantó". "No sino por vos." Agraviados ambos fueron a querellarse, y el juez, vista su locura y porfía, dejólos gastar, y al cabo sentenció que por él cantó, por lo que le valió, y así es el refrán todo: "Por vos cantó el cuclillo; no cantó sino por vos; que ni por vos, ni por vos, sino por mí cantó". Dicen que el cuco no hace nido sino que en los de otras aves come los huevos y pone los suyos, y así se los crían, y parece con esto que los encornuda; de aquí tiene el vulgo el canto del cuclillo por nota de cornudo, y motejan diciendo cuco, cucu. No creo la historia por ser contra la naturaleza de los animales, que aman sus hijos; sino que de la voz de su canto cucu parece va a decir cuerno, y se le atribuye la patraña, porque se dijo cornado el que padece este agravio de su mujer.

(Gonzalo de CORREAS, Vocabulario de refranes y frases proverbiales, Burdeos, 1967, 479-480) 
Zween Lothringer / die sonst sehr gute Freund waren / reyseten mit einander über Feld / vnderwegen saß ein Guggauch auff einem Baum / vnd sang sein lieblich Gesang/ da wolt je einer den andern überreden/ er hätte jhme gegugget/ vnd als keiner dem andern nachgeben wolt / geriethen síe erstlich zu Scheltworten / vnd folgends gar zu Streichen /schlugen / vnnd verwundten einander sehr übel / daß man sie in dem negst gelegnen Dorff curieren mußte: darauff sie bey selbigem Richter ein Rechtshandel anfiengen / vnnd alla durch selbigen Richters List so lang mit Rechten vnd trölen auffgehalten worden / biß sie vmb jhr Gut kommen / endlichen führet der Richter beyde auff die Straß zu dem Baum / da der Gugger gegugget hat / vnd fragt sie: auff welchem Ast der Gugger gesessen? vnnd als sie vngleiche Meynungen hatten / sprach er : ist er nicht auff disem mittelsten Ast gesessen? Sie sprachen ja / da wand sich der Richter zu dem einen / vnnd sagt: der Gugger hatte jhme nicht gegugget / hernach zu dem andern / so hat er dir auch nit gegugget/ sonder er hat mir geguget/ da waren die zween entscheiden/ machten Friden / vnnd trancken wider mit einander.

(Elfriede MOSER-RATH, Lustige Gesellschaft. Schwank und Witz des 17. und 18. Jabrhunderts in kultur-und sozialgeschichtlichem Kontext, Stuttgart, Metzler, 1984, Nr. 147)

\section{PARA QUEM CANTA O CUCO?}

Dois vizinhos ouviram cantar o cuco, e tomaram como agouro que era sinal de infidelidade de suas mulheres. Disse um:

- O cuco cantou mas foi para ti.

— Nada, isso não pode ser. Para ti é que ele cantou.

Pegam de teimar, e como nenhum cedia resolveram ir consultar um letrado. Chegaram lá, o letrado ouviuos, e depois de botar a livraria abaixo, disse:

- Deposite cada um dois pintos antes de tudo.

Os vizinhos entregaram o dinheiro ao letrado, ansiosos de ouvirem a sua sorte; e depois que ele meteu os pintos na algibeira, fingiu um semblante triste, e disse:

— Váose embora na paz do Senhor, porque para mim é que cantou o cuco.

(Teófilo BRAGA, Contos Tradicionais do Povo Português, vol. I, Lisboa, Dom Quixote, 1987, p. 262-263. Recollido no Porto). 